Jurnal Kependudukan Indonesia | Vol. 14 No. 1 Juni 2019|77-92

JURNAL KEPENDUDUKAN INDONESIA

p-ISSN : 1907-2902 (Print)

e-ISSN : 2502-8537 (Online)

\title{
GERAKAN AYO SEKOLAH DI KABUPATEN BOJONEGORO: PENINGKATAN SUMBER DAYA MANUSIA MELALUI PENDIDIKAN UNTUK MENYONGSONG BONUS DEMOGRAFI
}

\section{(THE "AYO SEKOLAH” MOVEMENT IN BOJONEGORO REGENCY: IMPROVING HUMAN RESOURCES THROUGH EDUCATION TO SUPPORT DEMOGRAPHIC BONUS)}

\author{
Sonyaruri Satiti \\ Pusat Studi Kependudukan dan Kebijakan, Universitas Gadjah Mada
}

Korespondensi penulis: kitna_onya@yahoo.com

\begin{abstract}
Improving the quality of human resources through education is one of the ways to benefit from the window of opportunity. The Government of Indonesia and many local governments have been conducting programs to provide easier access to education to prevent dropouts. The Local Government of Bojonegoro has been implementing a program called "Ayo Sekolah" to curb dropouts. This paper aims to describe the conditions of education in Bojonegoro District and the implementation of the "Ayo Sekolah" Program in Bojonegoro District. The analysis is based on the result of research on the program. The research used a quantitative and qualitative approach. Qualitative data is collected through in-depth interviews, while secondary data are used for quantitative analysis. The result of the study shows that the "Ayo Sekolah" Program in Bojonegoro District that has been running since 2015 has significantly reduced dropout rates. The percentage of the drop-off rates for Bojonegoro Regency high school/vocational/MA in 2013-2017 decreased even though only 0.20 percent.
\end{abstract}

Keywords: Demographic Dividend, Education, Ayo Sekolah Movement

\begin{abstract}
Abstrak
Meningkatkan kualitas sumber daya manusia (SDM) melalui pendidikan merupakan salah satu upaya untuk dapat memanfaatkan jendela kesempatan. Pemerintah pusat maupun daerah menggulirkan program agar masyarakat semakin mudah mengakses dan memperoleh layanan pendidikan, sehingga tidak ada anak putus sekolah. Untuk menekan angka putus sekolah, Pemerintah Kabupaten (Pemkab) Bojonegoro melaksanakan program "Gerakan Ayo Sekolah" (GAS). Tulisan ini bertujuan untuk mendeskripsikan kondisi pendidikan dan pelaksanaan program GAS di Kabupaten Bojonegoro. Data yang digunakan adalah hasil penelitian lapangan yang dikumpulkan menggunakan kombinasi pendekatan kuantitatif dan kualitatif. Data kuantitatif yang digunakan adalah data sekunder, sedangkan data kualitatif dikumpulkan melalui wawancara mendalam. Hasil penelitian menunjukkan bahwa GAS di Kabupaten Bojonegoro yang dilaksanakan sejak tahun 2015 cukup signifikan dalam menurunkan angka putus sekolah. Persentase angka putus sekolah SMA/sederajat di Kabupaten Bojonegoro tahun 2013-2017 mengalami penurunan meskipun hanya sebesar 0,20 persen.
\end{abstract}

Kata Kunci: Bonus Demografi, Pendidikan, Gerakan Ayo Sekolah 


\section{PENDAHULUAN}

Indonesia menempati urutan keempat negara dengan jumlah penduduk terbesar di dunia, setelah Republik Rakyat Tiongkok, India, dan Amerika Serikat. Pada tahun 2019 jumlahnya diproyeksikan mencapai sekitar 267 juta jiwa. Dilihat dari komposisi menurut kelompok umur, jumlah penduduk usia produktif (15-64 tahun) mencapai 183,36 juta jiwa atau sebesar 68,7 persen dari total populasi (Bappenas, 2018). Perbandingan penduduk usia produktif lebih besar dari penduduk nonproduktif menyebabkan rasio ketergantungan menurun dan memberikan peluang yang disebut bonus demografi. Bonus demografi membuka peluang untuk meningkatkan kesejahteraan masyarakat. Namun demikian, bonus demografi akan berdampak sebaliknya jika tidak diimbangi dengan kualitas sumber daya manusia (SDM) yang memadai (Rosadi, 2017). Kondisi SDM yang berkualitas rendah akan menghambat pembangunan yang pada akhirnya berdampak pada masyarakatnya sendiri dengan tidak tercapainya tujuan pembangunan, yaitu meningkatkan kesejahteraan masyarakat.

Salah satu acuan yang digunakan untuk melihat kualitas SDM adalah Human Development Index (HDI) atau Indeks Pembangunan Manusia (IPM). IPM merupakan indikator penting untuk mengukur keberhasilan dalam upaya membangun kualitas hidup manusia (masyarakat/penduduk). Berdasarkan laporan United Nations Development Program (UNDP) tahun 2018 IPM Indonesia menempati urutan ke-113 dari 188 negara dengan IPM sebesar 71,39. IPM Indonesia masih di bawah negara Asia Tenggara lainnya seperti Singapura, Brunei Darussalam, Malaysia, dan Thailand. Hal tersebut menunjukkan bahwa kualitas sumber daya manusia di Indonesia masih perlu ditingkatkan.

IPM Indonesia tahun 2018 tersebut tidak mencapai target APBN 2018. Kondisi ini sama dengan satu tahun sebelumnya. Pada tahun 2017, IPM lebih rendah dari target 71,50. Belum tercapainya target IPM ini antara lain disebabkan oleh masih rendahnya pembangunan pendidikan. Kondisi tersebut menunjukkan adanya masalah di sektor pendidikan di Indonesia.

IPM Kabupaten Bojonegoro tahun 2016 masih rendah jika dibandingkan dengan kabupaten lainnya di Provinsi Jawa Timur. Kabupaten Bojonegoro berada pada peringkat ke 26 dari 38 kabupaten/kota di Provinsi Jawa Timur dan berada di bawah rata-rata IPM provinsi tersebut. Data pada tabel 1 menunjukkan IPM Kabupaten Bojonegoro tahun 2010 - 2016.
Tabel 1. Indeks Pembangunan Manusia Kabupaten Bojonegoro, Tahun 2010-2016

\begin{tabular}{cccccc}
\hline Tahun & IPM & AHH & EYS & MYS & Pengeluaran \\
\hline 2010 & 62,19 & 69,8 & 11,14 & 5,51 & $8.086,59$ \\
2011 & 63,22 & 69,89 & 11,43 & 5,7 & $8.413,29$ \\
2012 & 64,2 & 69,98 & 11,74 & 5,8 & $8.809,44$ \\
2013 & 64,85 & 70,07 & 12,04 & 5,9 & $8.934,19$ \\
2014 & 65,27 & 70,11 & 12,08 & 6,14 & $8.963,65$ \\
2015 & 66,17 & 70,51 & 12,09 & 6,64 & $8.993,21$ \\
2016 & 66,73 & 70,67 & 12,11 & 6,65 & 9420
\end{tabular}

Sumber: BPS Kabupaten Bojonegoro 2010, 2011, 2012, 2013, 2014, 2015 dan 2016.

Pendidikan merupakan salah satu upaya penting dalam meningkatkan kualitas SDM suatu negara. Namun demikian, di Indonesia berbagai upaya pembangunan pendidikan yang dijalankan dirasakan belum optimal hasilnya. Dalam rencana strategis (Renstra) Kementerian Pendidikan dan Kebudayaan (Kemendikbud) dinyatakan bahwa target angka putus sekolah hanya sebesar satu persen pada masing-masing jenjang pendidikan (SD/SMP/SMA). Jenjang pendidikan sekolah dasar (SD) sudah mencapai target tersebut (0,51 persen), sementara angka putus sekolah SMP maupun SMA masih belum dapat mencapai target (masing-masing sebanyak 1,67 persen dan 2,94 persen berturut-turut). Pada tahun 2018, lima dari 1.000 anak SD putus sekolah. Angka tersebut semakin besar pada jenjang pendidikan sekolah menengah (SM)/sederajat. Tercatat 29 dari 1.000 anak SM/sederajat putus sekolah. Angka putus sekolah di perdesaan lebih besar dibandingkan dengan di perkotaan. Selisih angka perkotaan dan perdesaan semakin besar seiring meningkatnya jenjang pendidikan. Selanjutnya, angka putus sekolah laki-laki lebih besar dibandingkan perempuan pada seluruh jenjang pendidikan. Persentase anak yang tidak bersekolah semakin meningkat sejalan dengan bertambahnya usia. Dibandingkan dengan daerah perkotaan, persentase anak yang tidak bersekolah lebih besar daripada di wilayah perdesaan (BPS, 2018).

Angka Partisipasi Murni (APM) pada setiap jenjang pendidikan masih belum mencapai 100 persen. Hal ini menunjukkan bahwa belum seluruh penduduk bersekolah di jenjang pendidikan yang sesuai dengan usia mereka. Namun, jika disandingkan dengan target capaian APM SD/MI yang dicantumkan dalam Rencana Pembangunan Jangka Menengah Nasional (RPJMN) tahun 2015-2019 (91,3 persen), APM SD/sederajat pada tahun 2018 telah melampaui target RPJMN tahun 2019, yaitu sebesar 97,58 persen. 
Banyak faktor yang menyebabkan anak putus sekolah dan tidak bersekolah lagi. Data yang dikeluarkan oleh Badan Pusat Statistik menunjukkan bahwa di tingkat provinsi dan kabupaten terdapat kelompok anak-anak tertentu yang paling rentan dan sebagian besar berasal dari keluarga miskin, sehingga tidak mampu melanjutkan pendidikan ke jenjang selanjutnya. Hasil penelitian Pusat Studi Kependudukan dan Kebijakan Universitas Gadjah Mada (PSKK-UGM) tentang Hasil Bantuan Siswa Miskin Endline di Sumatera Utara, Jawa Barat, Jawa Timur, Nusa Tenggara Barat (NTB), Nusa Tenggara Timur (NTT), dan Sulawesi Selatan memperlihatkan sebanyak 47,3 persen responden tidak bersekolah lagi karena masalah biaya, 31 persen karena ingin bekerja membantu orang tua, serta 9,4 persen karena ingin melanjutkan pendidikan nonformal seperti pesantren atau mengambil kursus keterampilan. Mereka yang tidak melanjutkan sekolah ini sebagian besar berijazah terakhir sekolah dasar (42,1 persen) dan tidak memiliki ijazah (30,7 persen) (PSKK UGM, 2013). Dengan pendidikan yang rendah, mereka akan kesulitan bersaing dalam memperoleh pekerjaan karena kurangnya keterampilan dan tidak memenuhi persyaratan minimal yang dibutuhkan. Hal yang sama juga terjadi di Kabupaten Bojonegoro. Dalam tiga tahun terakhir tercatat sekitar 5.000 siswa SD, sekolah lanjutan tingkat pertama (SLTP), dan sekolah lanjutan tingkat atas (SLTA) yang tidak melanjutkan sekolah karena kesulitan ekonomi dan masuk ke pasar kerja.

Pemerintah Kabupaten Bojonegoro menyadari pentingnya peningkatan kualitas SDM melalui pendidikan dalam rangka menyongsong bonus demografi. Bonus demografi pada usia produktif harus dimaksimalkan dan dipersiapkan sebaik mungkin. Oleh karena itu, Pemerintah Kabupaten Bojonegoro terus melakukan upaya peningkatan kualitas SDM di daerahnya. Untuk menekan angka putus sekolah sejak tahun 2015 Pemerintah Kabupaten Bojonegoro melaksanakan program "Gerakan Ayo Sekolah" (GAS). Program ini dirancang sebagai bentuk keprihatinan Pemerintah Kabupaten Bojonegoro terhadap masih adanya anak-anak usia sekolah yang tidak bisa sekolah dan banyak pula diantara mereka yang sudah sekolah terpaksa putus di tengah jalan. GAS merupakan program kerja nyata yang dilaksanakan oleh Pemerintah Kabupaten Bojonegoro dengan memberikan bantuan dana kepada anak-anak usia sekolah, khususnya yang duduk di bangku SMA/sederajat. Pemerintah Kabupaten Bojonegoro meyakini bahwa meningkatkan pendidikan akan meningkatkan kualitas dan daya saing masyarakat.

Berdasarkan latar belakang permasalahan di atas, maka tulisan ini akan mendeskripsikan: (1) kondisi dan permasalahan pendidikan di Kabupaten Bojonegoro saat ini, (2) implementasi GAS di Kabupaten Bojonegoro, dan (3) efektivitas GAS dalam menurunkan angka putus sekolah.

Tulisan ini merupakan hasil penelitian deskriptif untuk menyajikan gambaran yang spesifik mengenai situasi atau kondisi sosial (Neuman, 1997: 19-20). Penelitian deskriptif banyak digunakan dalam penelitian yang terkait dengan suatu kebijakan atau program, sebagaimana fokus penelitian ini. Penelitian ini menggunakan pendekatan kualitatif, dengan mengambil strategi studi kasus di Kabupaten Bojonegoro. Melalui pendekatan kualitatif, penelitian ini diharapkan dapat mengetahui kebijakan pemerintah secara komprehensif dalam rangka meningkatkan kualitas SDM melalui pendidikan dengan GAS.

Data yang digunakan dalam penelitian ini diperoleh dari Satuan Kerja Pemerintah Daerah (SKPD) Kabupaten Bojonegoro, khususnya Kantor Bupati Bojonegoro, Kementerian Agama, Dinas Pendidikan, serta guru atau kepala sekolah dan siswa beserta orang tua siswa penerima Dana Alokasi Khusus (DAK) Bidang Pendidikan dari GAS. Pengumpulan data dilakukan melalui wawancara mendalam dan observasi. Wawancara mendalam dimaksudkan untuk mengetahui pendapat informan terkait dengan pelaksanaan GAS selama ini serta faktor-faktor yang berpengaruh terhadap angka putus sekolah di Kabupaten Bojonegoro. Wawancara dilakukan dengan siswa dan orang tua siswa penerima DAK Bidang Pendidikan dari GAS, guru atau kepala sekolah yang terlibat dalam pelaksanaan GAS, kepala desa, Dinas Pendidikan, dan Kantor Kementerian Agama.

Analisis data kualitatif dilakukan secara deskriptif (Miles \& Huberman, 1992: 20-23, Creswell, 2010: 276). Informasi diolah dan direduksi untuk memperoleh tema-tema umum dalam rangka memahami konsep dan topik yang ditemukan di lapangan. Langkah selanjutnya adalah menginterpretasikan topik yang muncul. Tahap terakhir adalah menarik kesimpulan sekaligus memberikan rekomendasi.

\section{PELUANG BONUS DEMOGRAFI DI KABUPATEN BOJONEGORO}

Dinamika penduduk terjadi akibat kelahiran, kematian, dan migrasi masuk serta keluar dari suatu daerah. Ringkasnya, dinamika penduduk disebabkan karena pertumbuhan alamiah dan migrasi neto. Dinamika penduduk inilah yang menyebabkan transisi demografi, yaitu perubahan kondisi penduduk dari pertumbuhan penduduk yang rendah dengan tingkat fertilitas dan mortalitas yang tinggi menuju pertumbuhan penduduk 
yang rendah dengan tingkat fertilitas dan mortalitas yang rendah.

Dalam transisi demografi ini, ada masa terjadinya penurunan fertilitas dalam jangka panjang yang menyebabkan perubahan struktur penduduk, terutama penduduk usia produktif dan nonproduktif. Perbandingan antara kelompok penduduk usia produktif dan nonproduktif ini dinyatakan sebagai rasio ketergantungan, yaitu rasio antara penduduk nonproduktif terhadap penduduk usia produktif. Jika pertumbuhan penduduk usia kerja lebih pesat dibanding pertumbuhan penduduk di luar usia kerja, maka rasio ketergantungan secara dinamis akan menurun. Keuntungan ekonomis akibat penurunan rasio ketergantungan inilah yang disebut dengan bonus demografi (Adioetomo, 2005).

Turunnya rasio ketergantungan pada suatu saat akan mencapai titik terendah dan berbalik meningkat kembali. Saat rasio ketergantungan menunjukkan angka yang paling rendah, yang biasanya berada di bawah 50 persen (jumlah penduduk usia kerja sekitar dua kali lebih besar dibandingkan dengan penduduk bukan usia kerja) disebut jendela kesempatan (the window of opportunity). Kesempatan tersebut hanya terjadi satu kali dalam seluruh perjalanan kehidupan penduduk. Oleh karena itu, kualitas penduduk usia produktif perlu ditingkatkan agar mampu menanggung beban penduduk usia nonproduktif.

Untuk memanfaatkan bonus demografi dan jendela kesempatan, penting dipahami kapan bonus demografi tersebut terjadi. Tidak seperti bonus yang lain, bonus demografi bukanlah suatu yang perlu ditunggu namun yang lebih penting lagi adalah persiapan pembangunan SDM sebelum terjadinya jendela kesempatan. Dalam konteks ini, persiapannya adalah meningkatkan kualitas SDM penduduk yang akan memasuki usia produktif. Penduduk usia produktif ini harus berpendidikan, sehat, dan mempunyai ketrampilan kerja yang baik.

Menurut hasil Sensus Penduduk 1995, penduduk Kabupaten Bojonegoro berjumlah 1,1 juta jiwa. Laju pertumbuhan penduduk selama kurun waktu 1980-1990 tercatat sebesar satu persen per tahun dan pertumbuhan selama tahun 1990-1995 adalah 0,83 persen per tahun. Diperkirakan laju pertumbuhan penduduk terus menurun sampai sekitar 0,10 persen dalam kurun 20152020. Meskipun angka pertumbuhan penduduk menurun, penduduk Kabupaten Bojonegoro akan terus meningkat jumlahnya dari 1,0 juta pada tahun 1985 menjadi 1,2 juta pada tahun 2020 (BPS, 2010).

Jumlah penduduk Kabupaten Bojonegoro berdasarkan proyeksi yang dilakukan oleh BPS-UNFPA (2015) yaitu sebanyak 1.212.301 jiwa pada tahun 2010. Angka ini ternyata lebih tinggi (over estimated) dibandingkan dengan hasil Sensus Penduduk tahun 2010 (SP 2010), yaitu sebanyak 1.209.073 jiwa. Namun, perbedaan perkiraan jumlah ini tidak mengubah struktur penduduk menurut kelompok usia dan indeks ketergantungan sehingga analisis demografi ini masih dapat digunakan sebagai bahan untuk analisis pendidikan.

Pola pertumbuhan penduduk Kabupaten Bojonegoro di masa depan diperkirakan akan berbeda dengan pola pertumbuhan yang terjadi dalam sepuluh tahun terakhir. Semakin sempurnanya pelayanan kesehatan, pendidikan, dan peningkatan daya beli telah dan akan menurunkan tingkat kematian dan kelahiran sehingga terjadilah sebuah transisi demografi. Gejala transisi demografi ini memperlihatkan susunan penduduk yang makin sempurna yang dapat ditunjukkan dengan pergeseran struktur penduduk dari tingkat fertilitas dan mortalitas tinggi ke pola perkembangan penduduk yang memiliki tingkat fertilitas dan mortalitas rendah. Transisi demografi ini merupakan implikasi dari terjadinya perubahan sikap, perilaku, dan cara hidup sebagian besar penduduk Indonesia yang semakin efisien dan produktif serta perubahan cara hidup yang semakin modern.

\section{Gambar 1 Dependency Ratio Kabupaten Bojonegoro, Tahun 2010-2020}

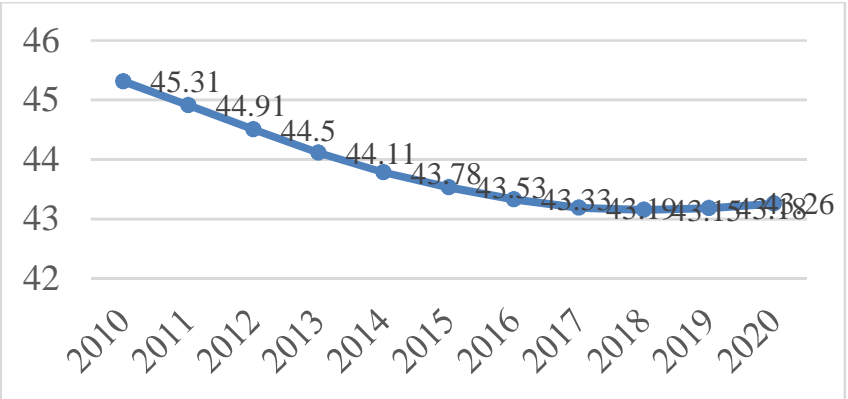

Sumber: Proyeksi Penduduk Kabupaten/Kota Provinsi Jawa Timur 2010-2020, BPS-UNFPA

Bertolak dari pola pertumbuhan penduduk seperti itu, susunan umur penduduk Kabupaten Bojonegoro pada awal abad ke-21 mulai bergeser dari dominasi umur penduduk muda menuju penduduk dewasa dan tua. Struktur penduduk akan berubah dari bentuk piramida (dominasi usia muda) ke bentuk stupa (dominasi usia dewasa). Perubahan susunan penduduk ini menunjukkan bahwa susunan penduduk Kabupaten Bojonegoro pada tahun 2020 ke depan akan mulai bergeser dari dominasi penduduk muda ke penduduk usia produktif. Struktur penduduk inilah yang disebut bonus demografi karena proporsi penduduk usia produktif (usia 15-65) meningkat, dan proporsi 
Gerakan Ayo Sekolah di...| Sonyaruri Satiti

penduduk usia tidak produktif (usia 0-14 tahun dan > 65 tahun) menurun. Gejala ini memperlihatkan menurunnya rasio ketergantungan (dependency ratio) seperti dapat dilihat pada Gambar 1.

Salah satu indikator perubahan itu adalah menurunnya angka ketergantungan (dependency ratio) selama 10 tahun terakhir. Perubahan tersebut terlihat pada pola ketergantungan penduduk umur muda (0-14) atau tua (65 tahun ke atas) terhadap kelompok usia produktif (usia antara 15-64 tahun). Susunan umur penduduk di Kabupaten Bojonegoro pada awal abad ke-21 akan bergeser ke dominasi umur penduduk tua. Transisi demografi tersebut menimbulkan apa yang disebut "bonus demografi" yang akan terjadi tahun 2010-2025.

Kabupaten Bojonegoro tengah berada dalam periode transisi struktur penduduk usia produktif. Pada kurun waktu 2020-2030, penurunan rasio ketergantungan Kabupaten Bojonegoro akan mencapai angka terendah. Penurunan rasio ketergantungan yang dipengaruhi oleh penurunan proporsi penduduk muda memberi dampak positif bagi pembangunan karena mengurangi besarnya investasi untuk pemenuhan kebutuhan penduduk muda. Dengan demikian, penggunaan sumber daya dapat dialihkan untuk memacu pertumbuhan ekonomi dan peningkatan kesejahteraan keluarga (Adioetomo, 2005). Implikasi penting dari kondisi ini adalah semakin pentingnya penyediaan lapangan kerja agar perekonomian dapat memanfaatkan secara maksimal besarnya proporsi penduduk usia produktif. Lebih penting lagi, bila tingkat pendidikan secara umum diasumsikan terus membaik, produktivitas perekonomian negara ini sesungguhnya dalam kondisi premium. Hal tersebut akan sangat bermanfaat untuk tujuan percepatan maupun perluasan pembangunan ekonomi.

Perubahan susunan penduduk Kabupaten Bojonegoro mulai bergeser dari dominasi penduduk muda ke penduduk usia produktif. Angka beban ketergantungan setiap tahun cenderung mengalami penurunan. Pada tahun 2013 angka beban tanggungan sebesar 44,11 persen. Hal ini berarti bahwa 100 penduduk usia produktif menanggung sekitar 45 penduduk usia tidak produktif. Pada tahun 2014 angka beban tanggungan penduduk menurun menjadi 43,78 persen, pada tahun 2015 turun menjadi 43,53 persen, dan tahun 2016 menjadi 43,33 persen. Pada tahun 2017 angka beban tanggungan penduduk berada pada posisi 43,11 persen. Artinya, setiap 100 penduduk produktif masih menanggung beban 44 penduduk tidak produktif.

\section{Tabel 2. Komposisi Penduduk (\%) dan Angka Beban Ketergantungan Kabupaten Bojonegoro, Tahun 2013-2017}

\begin{tabular}{ccccc}
\hline Tahun & $\begin{array}{c}0-14 \\
\text { Tahun }\end{array}$ & $\begin{array}{c}15-64 \\
\text { Tahun }\end{array}$ & $\begin{array}{c}65 \\
\text { Tahun+ }\end{array}$ & $\begin{array}{c}\text { Angka Beban } \\
\text { Ketergantungan } \\
\text { (jiwa) }\end{array}$ \\
\hline 2013 & 22,47 & 69,39 & 8,14 & 44,11 \\
2014 & 22,18 & 69,55 & 8,27 & 43,78 \\
2015 & 21,90 & 69,67 & 8,43 & 43,53 \\
2016 & 21,62 & 69,77 & 8,61 & 43,33 \\
2017 & 21,34 & 69,84 & 8,82 & 43,19 \\
\hline
\end{tabular}

Sumber: Proyeksi Penduduk Kabupaten/Kota Provinsi Jawa Timur 2010-2020

Angka ketergantungan yang rendah dapat mendorong perekonomian tumbuh lebih baik, karena berpeluang lebih besar untuk melakukan investasi manusia dan meningkatkan produksi. Rasio ketergantungan yang cenderung terus menurun belakangan ini diperkirakan akan mencapai titik terendah pada periode 2020-2030. Pada periode itu akan terdapat peluang ekonomi terbaik bila penduduk usia produktifnya berkualitas. Namun sebaliknya, perlu diwaspadai jika sebagian besar dari mereka tidak bekerja disebabkan gagal terserap pasar kerja. Kondisi ini dapat menjadi persoalan tersendiri dan pada gilirannya akan menimbulkan instabilitas sosial maupun politik.

Menurunnya angka beban ketergantungan diikuti pula dengan menurunnya proporsi penduduk usia muda (014 tahun) sebagai dampak dari menurunnya laju pertumbuhan penduduk. Data pada tabel 2 menunjukkan bahwa pada tahun 2013 ada sebanyak 22,47 persen penduduk yang berusia muda (0-14 tahun) dan turun menjadi 21,62 persen pada tahun 2016. Hingga tahun 2017 proporsi penduduk usia 0-14 tahun turun menjadi 21,34 persen.

Pada tabel 2 juga dapat dilihat bahwa struktur umur penduduk Bojonegoro masih didominasi oleh penduduk usia produktif yang berdasarkan Proyeksi Penduduk 2010-2020 mencapai 69,39 persen pada tahun 2013. Proporsi ini meningkat menjadi 69,67 persen pada tahun 2015 dan 69,84 persen pada tahun 2017. Hal ini menunjukkan bahwa penduduk usia produktif di Bojonegoro menjadi sangat potensial sebagai modal dasar yang besar untuk pembangunan. Sementara itu, proporsi penduduk usia lanjut (65 tahun ke atas) semakin bertambah dari 8,14 persen pada tahun 2013, menjadi 8,43 persen pada tahun 2015 dan 8,82 persen pada tahun 2017.

Bonus demografi memberikan beberapa keuntungan bagi Kabupaten Bojonegoro, yaitu adanya peluang untuk mendapatkan keuntungan ekonomis karena penurunan rasio ketergantungan dan/atau penurunan 
proporsi penduduk muda dapat mengurangi besarnya biaya investasi untuk pemenuhan kebutuhan layanan umum. Agar bonus demografi ini benar-benar dapat memberikan keuntungan, diperlukan penyiapan supaya penduduk usia produktif di Kabupaten Bojonegoro pada masa-masa terjadinya bonus demografi benarbenar memiliki kualitas dan produktivitas yang diinginkan. Penyiapan tersebut antara lain dilakukan melalui program pendidikan. Dengan demikian, pembangunan sektor pendidikan menjadi penting dan perlu mendapat prioritas (Suryadi, 1999).

Pendidikan merupakan salah satu faktor penting dalam pembangunan manusia. Potensi yang dimiliki manusia dapat dikembangkan secara optimal melalui pendidikan. Pendidikan dianggap sebagai sarana investasi yang mampu meningkatkan pengetahuan, keterampilan, dan keahlian tenaga kerja sebagai modal agar bisa bekerja lebih produktif, sehingga dapat meningkatkan penghasilan di masa datang.

Pentingnya pendidikan sudah sejak lama disadari seluruh bangsa Indonesia sebagaimana tertuang dalam pembukaan Undang-Undang dasar 1945 yang menyatakan bahwa salah satu tujuan dibentuknya NKRI adalah mencerdaskan kehidupan bangsa. Undang-Undang Dasar Negara Republik Indonesia Tahun 1945 mengamanatkan kepada Pemerintah untuk mengusahakan dan menyelenggarakan satu sistem pendidikan nasional yang meningkatkan keimanan dan ketakwaan kepada Tuhan Yang Maha Esa serta akhlak mulia dalam rangka mencerdaskan kehidupan bangsa. Pemerintah mengimplementasikan amanat tersebut ke dalam Undang-Undang No. 20 Tahun 2003 tentang Sistem Pendidikan Nasional yang menjelaskan bahwa pendidikan adalah usaha untuk menyelenggarakan suasana belajar dan proses pembelajaran agar peserta didik terlibat secara aktif mengembangkan potensi dirinya untuk memiliki kekuatan spiritual keagamaan, pengendalian diri, kepribadian, kecerdasan, akhlak mulia, serta keterampilan yang diperlukan dirinya, masyarakat, bangsa, dan negara. Hingga saat ini, meningkatkan kualitas SDM melalui pendidikan menjadi salah satu agenda dalam menentukan arah kebijakan pembangunan yang disusun dalam Rencana Strategis (Renstra), Rencana Pembangunan Jangka Menengah (RPJM) dan Rencana Pembangunan Jangka Panjang (RPJP), serta dokumen lain yang memuat berbagai hal berkaitan dengan kebijakan pembangunan pendidikan yang mengacu pada RPJM dan RPJP Nasional. Sasaran RPJM bidang pendidikan antara lain meningkatnya akses masyarakat terhadap pendidikan dan meningkatkan mutu pendidikan.

\section{MODAL MANUSIA}

Investasi di bidang SDM atau human capital dimaksudkan untuk meningkatkan produktivitas kerja yang pada gilirannya dapat meningkatkan penghasilan. Investasi di bidang SDM dapat dilakukan dalam bentuk: (1) pendidikan dan latihan, (2) migrasi dan urbanisasi, serta (3) perbaikan gizi dan kesehatan. Dalam teori SDM di bidang pendidikan disebutkan bahwa seseorang dapat meningkatkan pendapatan melalui peningkatan pendidikan dan latihan. Setiap tambahan satu tahun sekolah akan meningkatkan kemampuan kerja dan tingkat pendapatan. Akan tetapi, mengikuti sekolah berarti menunda penerimaan pendapatan selama beberapa tahun. Selain itu, mereka yang meneruskan pendidikan harus membayar biaya sekolah seperti membeli buku-buku dan peralatan sekolah, transportasi dan berbagai kebutuhan lainnya. Teori SDM mengemukakan bahwa seseorang akan meneruskan sekolah, misalnya dari SMA ke Sarjana Strata I dengan berbagai pertimbangan. Bila sampai tingkat tertentu, penghasilan yang diperoleh lulusan pendidikan Sarjana Strata I lebih besar daripada SMA, seseorang rela menerima penghasilan yang tertunda, bahkan bersedia mengeluarkan biaya sebagai bentuk investasi di masa mendatang (Simanjuntak, 1985).

Ogawa, Jones dan Williamson (1993) mengatakan bahwa di negara-negara di wilayah Pacific Rim, termasuk Indonesia telah terjadi human capital deepening. Artinya, telah ada upaya untuk meningkatkan kualitas SDM melalui investasi dan perluasan pendidikan. Upaya tersebut melibatkan komitmen yang cukup panjang dari negara-negara di wilayah Pasific Rim, termasuk Indonesia yang telah dimulai bahkan jauh sebelum adanya pertumbuhan ekonomi tinggi tahun 1970-1990-an. Ogawa, Jones dan Williamson (1993) mengadakan studi perbandingan tentang perluasan pendidikan di Indonesia, Malaysia, Thailand dan Filipina, yang meskipun negara-negara tersebut digolongkan mempunyai pertumbuhan ekonomi lambat dibanding dengan Asia Timur lainnya, namun telah terjadi perkembangan di bidang Pendidikan. Pemerintah Indonesia bahkan sejak awal telah memberikan komitmen untuk investasi pendidikan. Namun, sejak tahun 1980an hasil peningkatan pendidikan tersebut tidak dapat diimbangi dengan peningkatan permintaan terhadap tenaga kerja Ogawa, Jones dan Williamson (1993). Ogakawa, Jones dan Wiliamson mengasumsikan bahwa di tahun 1980an setiap pekerja yang akan memasuki masa pensiun adalah mereka yang buta huruf, dan akan digantikan oleh tiga orang calon pekerja dengan pendidikan yang lebih tinggi. Ini disebut sebagai push down effect dari pertumbuhan penduduk usia kerja muda dan peningkatan pendidikan yang pesat. Keadaan seperti ini 
juga dialami oleh negara tetangga lain dengan pertumbuhan penduduk tinggi.

Investasi pemerintah Indonesia untuk meningkatkan kualitas SDM melalui perluasan jangkauan pendidikan dasar telah membuahkan hasil. Komitmen mengejar ketertinggalan di bidang pendidikan memperlihatkan hasil yang signifikan. APM SD telah meningkat dengan pesat dan bahkan mencapai tingkat 'universal'. Perluasan jangkauan pendidikan dinikmati oleh sebagian besar masyarakat Indonesia (Adioetomo dalam Hull, 2005). Sebanyak 90 persen generasi kelahiran tahun 1980-1985 telah menamatkan pendidikan dasar. Sebesar 90 persen yang telah tamat SD telah melanjutkan ke jenjang pendidikan di atasnya, dan 60 persen generasi 1980-1985 telah menamatkan SLTP. Selanjutnya, sebesar 30-40 persen mencapai tamat SLTA.

Usaha mencerdaskan kehidupan bangsa lewat proses pendidikan dan pembudayaan tidak saja penting sebagai cara memanusiakan manusia, tetapi juga memiliki nilai pragmatik dalam mengembangkan kesejahteraan rakyat. Ki Hadjar Dewantara pernah berkata "Kemajuan sebuah bangsa terletak pada pendidikan dan pada generasi bangsa itu sendiri". Baginya, pendidikan merupakan wahana untuk membuat bangsa ini menjadi bangsa yang maju, bermartabat, sejahtera, dan merdeka lahir-batin. Untuk itu, Ki Hajar Dewantara punya semboyan yang indah, "Belajar seumur hidup, belajar dari kehidupan."

Peraih Hadiah Nobel di bidang ekonomi, Amartya Sen mengategorikan pendidikan sebagai "peluang-peluang sosial" (social opportunities) yang sangat fundamental dalam menciptakan kemerdekaan hakiki semua orang untuk hidup lebih baik dan layak. Menurut Sen (1999), akses terhadap pendidikan sebagai salah satu social opportunities ini penting, bukan hanya dalam rangka mencapai taraf hidup yang menyenangkan, melainkan juga penting bagi warga sebagai modal awal untuk berperan serta secara lebih efektif dalam aktivitas ekonomi-politik-kultural secara lebih baik.

Sen mencontohkan bahwa kebutaaksaraan akan menjadi penghambat utama seseorang untuk berperan serta dalam kegiatan-kegiatan ekonomi yang mempersyaratkan adanya kemampuan baca-tulis atau pengendalian mutu secara ketat. Hal yang sama juga akan terjadi dalam peran serta politik warga, dengan minimnya tingkat pendidikan yang juga akan menghambat partisipasi politik seseorang dalam beragam aktivitasnya (Sen, 1999). Singkat kata, pendidikan menjadi hal paling vital, merupakan kunci utama bagi kemajuan dan kesejahteraan sebuah bangsa dan umat manusia. Dalam penelitian Sen, pendapatan per kapita yang tinggi tidak secara otomatis akan membuat kehidupan manusia semakin baik. Pernyataan bahwa "pendapatan yang rendah sebagai penyebab kemiskinan" dianggap terlalu menyederhanakan masalah. Bagi Sen, ada penyebab yang lebih mendasar hingga terjadi keterbelakangan, yakni kualitas SDM. Menurut Sen, "pembangunan manusia (human development) adalah sekutu bagi masyarakat miskin."

\section{KONDISI PENDIDIKAN SAAT INI DI KABUPATEN BOJONEGORO: ANALISIS SITUASI DAN ISU STRATEGIS}

Kabupaten Bojonegoro merupakan kabupaten di Provinsi Jawa Timur yang terkenal dengan lumbung pangan negeri dan potensi alamnya, terutama penghasil minyak dan gas bumi. Minyak bumi menjadi penyumbang terbesar dalam perekonomian di Bojonegoro. Namun pada kenyataannya di Kabupaten Bojonegoro masih banyak ditemui anak putus sekolah. Data Badan Pusat Statistik (BPS) Kabupaten Bojonegoro Tahun 2015 menunjukkan bahwa jumlah anak putus sekolah pada tingkat Sekolah Dasar (SD) sebanyak 667 anak, 1.103 di tingkat Sekolah Menengah Pertama (SMP), dan 2.221 anak pada jenjang Sekolah Menengah Atas (SMA). Pada tingkat kecamatan, jumlah anak putus sekolah tertinggi adalah di Kecamatan Ngraho (439 anak), Kecamatan Ngasem (353 anak), Kecamatan Dander (383 anak), dan Kecamatan Sukosewu (215 anak). Selanjutnya data Dinas Pendidikan Kabupaten Bojonegoro Tahun 2018 menunjukkan secara umum jumlah anak putus sekolah usia 13-18 tahun sebanyak 2.020 orang.

\section{Tabel 3. Jumlah Anak Putus Sekolah Menurut Jenjang Pendidikan di Kabupaten Bojonegoro, Tahun 2015}

\begin{tabular}{lc}
\hline \multicolumn{1}{c}{ Jenjang Pendidikan } & $\begin{array}{c}\text { Jumlah Anak Putus } \\
\text { Sekolah }\end{array}$ \\
\hline Sekolah Dasar/SD & 667 \\
Sekolah Menengah & 1103 \\
Pertama/SMP & \\
Sekolah Menengah & 2221 \\
Atas/SMA & \\
\hline
\end{tabular}

Sumber: BPS Kabupaten Bojonegoro, 2015

Jumlah anak putus sekolah di Kabupaten Bojonegoro ini lebih rendah dibandingkan dengan jumlah anak putus sekolah di tingkat provinsi. Data Kementerian Pendidikan dan Kebudayaan (Kemendikbud) Tahun 2018 menunjukkan jumlah anak putus sekolah pada tingkat SD di Provinsi Jawa Timur sebanyak 1.980 anak, pada tingkat SMP sebanyak 7.532 anak dan 3.850 anak pada jenjang pendidikan SMA. 
Angka putus sekolah digunakan sebagai ukuran yang dapat menunjukkan kondisi pendidikan di suatu wilayah. Tingginya angka putus sekolah menunjukkan kondisi pendidikan yang belum cukup baik, dan sebaliknya. Selain angka putus sekolah, Angka Partisipasi Sekolah (APS) juga dapat menunjukkan kondisi pendidikan di suatu wilayah. APS menunjukkan siswa berumur 7-24 tahun yang sekolah. APS dapat digunakan untuk menunjukkan kemajuan pembangunan pendidikan. Semakin tinggi APS, menunjukkan kondisi pendidikan yang semakin baik. Sebaliknya, semakin rendah APS menunjukkan kondisi pendidikan yang tidak cukup baik. Indikator lain adalah APM yang mengukur ketepatan usia penduduk untuk mengenyam suatu jenjang pendidikan tertentu. Secara umum, nilai APM akan selalu lebih rendah dari APK karena APK memperhitungkan jumlah penduduk di luar usia sekolah pada suatu jenjang pendidikan tertentu, sedangkan APM hanya sebatas usia pada jenjang tersebut.

Selain memperlihatkan capaian di bidang pendidikan, APS merupakan ukuran daya serap lembaga pendidikan terhadap penduduk usia sekolah. APS digunakan sebagai indikator dasar untuk melihat akses penduduk pada fasilitas pendidikan bagi penduduk usia sekolah. APS menyatakan persentase penduduk yang bersekolah menurut kelompok usia sekolah, yaitu 7-12 tahun (SD), 13-15 tahun (SLTP) dan 16-18 tahun (SLTA). Semakin tinggi APS menunjukkan semakin banyak anak usia sekolah yang bersekolah di suatu daerah. Ini berarti semakin besar jumlah penduduk yang berkesempatan mengenyam pendidikan. APS yang tinggi juga menunjukkan terbukanya peluang yang lebih besar dalam mengakses pendidikan secara umum.

Secara umum APS di Provinsi Jawa Timur pada masing-masing kelompok usia sekolah mengalami peningkatan dalam lima tahun terakhir. Artinya, dari tahun ke tahun jumlah penduduk yang bersekolah di setiap kelompok usia tertentu semakin bertambah. Bersekolah bukan saja merupakan kebutuhan agar dapat membaca dan menulis, akan tetapi lebih sebagai sarana untuk memperoleh berbagai ilmu pengetahuan, bersosialisasi, dan memperoleh berbagai keterampilan.

Semakin meningkatnya APS di setiap kelompok usia penduduk Jawa Timur dapat memberikan gambaran bahwa ketersediaan sekolah pada setiap jenjang di provinsi ini semakin besar. Selain itu, sekolah-sekolah yang ada semakin mudah untuk diakses. Gambar 2 menunjukkan peningkatan APS penduduk Jawa Timur di setiap kelompok usia sekolah dalam lima tahun terakhir.

\section{Gambar 2. APS 7-12 Tahun, APS 13-15 Tahun, APS 16-18 Tahun di Provinsi Jawa Timur, Tahun 2013-2017 (\%)}

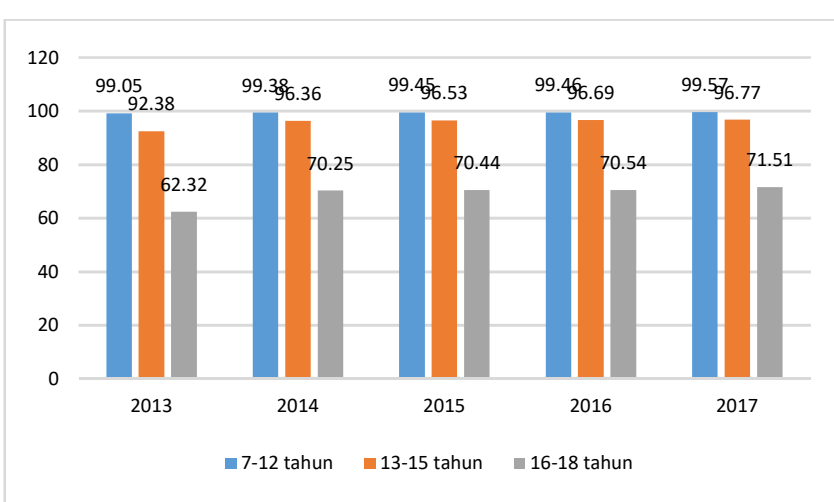

Sumber: Statistik Pendidikan Provinsi Jawa Timur, 2018.

APS kabupaten/kota di Jawa Timur cukup beragam. Secara umum APS kelompok usia 7-12 tahun dan kelompok usia 13-15 tahun sudah di atas 90 persen. Hal tersebut menandakan bahwa program wajib belajar 9 tahun telah dinikmati oleh hampir seluruh penduduk di Jawa Timur. Namun demikian, kondisi tersebut tidak berlaku pada kelompok usia 16-18 tahun. APS kelompok usia 16-18 tahun di berbagai wilayah masih belum merata. Sebagai contoh, daerah dengan APS kelompok usia 16-18 tahun tertinggi adalah Kota Kediri ( 90,01 persen), sedangkan yang terendah dimiliki oleh Kabupaten Bangkalan (49,42 persen) (BPS, 2018).

APS 712 tahun Jawa Timur dalam lima tahun terakhir berada pada kisaran 99 persen. Artinya, hampir seluruh penduduk Jawa Timur kelompok usia sekolah 712 tahun terdaftar dan masih aktif mengikuti pendidikan. Meskipun peningkatan persentasenya tidak terlalu besar, hal ini menunjukkan bahwa penduduk pada kelompok usia 712 tahun yang mengenyam pendidikan dasar terus bertambah. Dengan demikian program wajib belajar 6 tahun yang dicanangkan pemerintah Jawa Timur telah berhasil membawa penduduknya mengenyam pendidikan dasar. Kendati demikian, di tahun 2017 masih ada 0,43 persen penduduk pada kelompok usia 712 tahun yang belum/tidak bersekolah. Hal ini yang perlu mendapat perhatian, dengan fokus pada penyebab terjadinya kondisi tersebut dan upaya yang akan dilakukan untuk mengatasinya. Tersedianya sekolah sekolah dasar di berbagai wilayah hingga pelosok dan dukungan sarana prasarana lainnya diharapkan mampu mengatasi permasalahan tersebut. Selanjutnya, APS usia 13-15 tahun Jawa Timur mengalami peningkatan yang cukup signifikan yaitu sebesar 3,94 persen dari 92,83 persen di tahun 2013 menjadi 96,77 persen di tahun 2017. Hal ini menunjukkan bahwa jumlah penduduk kelompok usia 
13-15 tahun yang masih bersekolah terus meningkat dalam 5 tahun terakhir. Keberhasilan program wajib belajar 6 tahun yang digulirkan pemerintah Jawa Timur dan dilanjutkan dengan program wajib belajar 9 tahun dapat dilihat melalui APS pada kelompok usia ini.

APS pada kelompok usia 1618 tahun yang merepresentasikan usia sekolah tingkat lanjutan atas juga mengalami peningkatan yang sangat baik dalam periode tahun 2013-2017. Program wajib belajar 12 tahun yang mulai dicanangkan pemerintah Provinsi Jawa Timur sejak tahun 2012, sebagai lanjutan program pendidikan dasar sebelumnya menunjukkan pengaruhnya pada peningkatan APS kelompok usia ini. Terjadi peningkatan sebesar 9,19 persen yaitu dari 63,32 persen pada tahun 2013 menjadi 71,51 persen pada tahun 2017. Artinya, akses dan kesadaran penduduk Jawa Timur pada kelompok usia ini untuk bersekolah terus meningkat.

Semangat untuk terus berada di bangku sekolah hingga pendidikan yang lebih tinggi harus diimbangi dengan ketersediaan sekolah tingkat lanjutan dan sumber daya lainnya. Sebagian di antara penduduk Jawa Timur pada kelompok usia ini memiliki banyak keterbatasan dalam mengakses pendidikan. Akibatnya, APS untuk tingkat sekolah menengah atas lebih kecil dibandingkan dengan sekolah untuk kelompok usia di bawahnya. Hal ini ditunjukkan dengan masih adanya 28,49 persen penduduk Jawa Timur di kelompok usia 1618 tahun yang belum/tidak bersekolah pada tahun 2017 .

Upaya peningkatan pendidikan dasar dan menengah bagi penduduk Jawa Timur melalui program wajib belajar mendorong peningkatan APS pada setiap jenjang usia. Upaya tersebut diperkuat dengan program prioritas pemerintah Jawa Timur di bidang pendidikan lainnya seperti program pendidikan anak usia dini, peningkatan mutu pendidikan dan tenaga pendidik, serta program rencana jangka panjang dengan merintis wajib belajar 15 tahun.

Provinsi Jawa Timur memiliki 38 kabupaten/kota dengan karakteristik penduduknya yang beraneka ragam. Kendati demikian, capaian APS di masing masing kabupaten/kota pada setiap kelompok usia relatif sama antarwilayah yang berdekatan dan memiliki karakterteristik yang sejenis. khususnya untuk kelompok usia 712 tahun.

APS usia 712 tahun di sebagian besar kabupaten/kota di Jawa Timur hampir mencapai 100 persen. Artinya, peluang untuk mengakses sekolah bagi penduduk kelompok usia 712 tahun di sebagian besar kabupaten/kota di Jawa Timur terbuka lebar. Namun demikian, masih terdapat 15 kabupaten/kota dengan capaian APS penduduk usia 712 tahun di bawah angka provinsi. APS Kabupaten Bojonegoro pada masingmasing kelompok usia sekolah selama tahun 2016-2018 ditunjukkan pada tabel 4. APS laki-laki kelompok usia 7-12 tahun adalah 98,96 persen pada tahun 2016 dan meningkat menjadi 100 persen di tahun 2017. Namun demikian, pada tahun 2018 APS kelompok usia ini mengalami penurunan menjadi 98,86 persen. Selanjutnya, APS perempuan kelompok usia 7-12 tahun pada tahun 2016 sudah mencapai 100 persen. Akan tetapi, angka ini turun menjadi 98,31 pada tahun 2018. APS laki-laki kelompok usia 13-15 tahun pada tahun 2017 sebesar 97,19 persen, lebih tinggi dibandingkan APS pada tahun 2018 dan lebih rendah dari APS kelompok usia 7-12 tahun. Selanjutya, APS perempuan kelompok 13-15 tahun sebesar 92,05 tahun. Artinya, sebanyak 97,19 persen penduduk laki-laki usia 13-15 tahun dan 92,05 persen perempuan memiliki akses terhadap fasilitas pendidikan. Lebih lanjut, APS lakilaki dan perempuan kelompok usia 16-18 tahun sebesar 77,39 persen dan 83,23 persen secara berturut-turut pada tahun 2017. Angka ini lebih tinggi dibanding tahun 2016, baik untuk laki-laki maupun perempuan. Namun angka ini lebih kecil dibandingkan APS lakilaki maupun perempuan kelompok usia 13-15 tahun. Hal ini menunjukkan bahwa ada sekitar 19 persen penduduk laki-laki dan sekitar 8 persen penduduk perempuan usia 16-18 tahun tidak lagi melanjutkan Pendidikan ke jenjang SMA (BPS, 2018).

Banyaknya permasalahan kompleks dalam bidang pendidikan masih menjadi kendala bagi beberapa kabupaten/kota, termasuk Kabupaten Bojonegoro untuk dapat mencapai APS 100 persen pada kelompok usia 1315 tahun. Faktor sosial budaya masyarakat yang membatasi anak anaknya untuk bersekolah pada jenjang lebih tinggi menjadi salah satu penyebab belum tercapainya APS 100 persen pada kelompok usia ini. Alasan ekonomi, kasus kawin muda, harus membantu orang tua mencari nafkah, dan masih adanya pemahaman bahwa pendidikan bukan prioritas utama dalam hidupnya, merupakan permasalahan permasalahan yang masih sering ditemui di beberapa kabupaten/kota di wilayah Jawa Timur.

Tabel 4. Angka Partisipasi Sekolah Menurut Kelompok Usia Sekolah Kabupaten Bojonegoro, Tahun 2016-2018

\begin{tabular}{|c|c|c|c|c|c|c|}
\hline \multirow{2}{*}{$\begin{array}{c}\text { Kelomp } \\
\text { ok Usia }\end{array}$} & \multicolumn{2}{|c|}{2016} & \multicolumn{2}{|c|}{2017} & \multicolumn{2}{|c|}{2018} \\
\cline { 2 - 7 } Sekolah & Laki & Perempu & Laki- & Perempu & Laki & Perempu \\
-laki & an & laki & an & -laki & an \\
\hline $7-12$ & 98,9 & 100,00 & 100,0 & 100,00 & 98,8 & 98,31 \\
& 6 & & 0 & & 6 & \\
\hline
\end{tabular}


Jurnal Kependudukan Indonesia | Vol. 14, No. 1, Juni 2019|77-92

\begin{tabular}{|c|c|c|c|c|c|c|}
\hline $13-15$ & 95,6 & 93,51 & 97,19 & 92,05 & 78,5 & 88,76 \\
& 3 & & & & 9 & \\
\hline $16-18$ & 67,9 & 79,73 & 77,39 & 83,23 & 58,9 & 72,53 \\
& 4 & & & & 0 & \\
\hline
\end{tabular}

Sumber: Indikator Kesejahteraan Rakyat Kabupaten Bojonegoro, 2018.

Kemajuan pembangunan pendidikan bukanlah hal mudah untuk dicapai. Salah satu kendala yang dihadapi dalam pembangunan pendidikan antara lain rendahnya jangkauan (coverage) dan akses pada pelayanan pendidikan terutama bagi penduduk kurang mampu dan penduduk yang tinggal di perdesaan atau di daerah terpencil. Hal ini menyebabkan rendahnya partisipasi sekolah terutama pada jenjang pendidikan menengah dan tinggi. Rendahnya partisipasi sekolah di tingkat SMA Kabupaten Bojonegoro yang antara lain disebabkan oleh masih rendahnya jangkauan dan akses pada pendidikan bukan satu-satunya penghambat kemajuan pendidikan. Kemiskinan dan biaya sekolah yang tinggi turut menjadi penyebab rendahnya partisipasi sekolah dan pemicu banyaknya siswa yang putus sekolah atau tidak dapat melanjutkan ke jenjang pendidikan lebih tinggi. Rendahnya partisipasi sekolah dan relatif tingginya angka putus sekolah di tingkat SMA/sederajat mengindikasikan perlunya perhatian Pemerintah Kabupaten Bojonegoro pada pendidikan menengah terutama keberlanjutan siswa sekolah sampai tingkat Pendidikan tersebut.

Seperti yang telah dijelaskan sebelumnya, APS dapat digunakan untuk melihat partisipasi penduduk kelompok usia tertentu dalam pendidikan formal. Namun dalam analisis lebih lanjut, APS tidak dapat mengukur kesesuaian jenjang pendidikan yang sedang dijalani dengan kelompok usia tertentu. Untuk melihat partisipasi penduduk kelompok usia tertentu yang mengenyam pendidikan formal sesuai dengan kelompok usianya digunakan indikator APM.

Tabel 5. Angka Partisipasi Murni (APM) Formal dan Nonformal Penduduk Kabupaten Bojonegoro Menurut Karakteristik dan Jenjang Pendidikan, Tahun 2018

\begin{tabular}{lccc}
\hline Jenis Kelamin & SD & SMP & SMA \\
\hline Laki-laki & 98,86 & 78,59 & 58,90 \\
Perempuan & 98,31 & 88,76 & 72,53 \\
\hline Bojonegoro & 98,58 & 83,52 & 64,48
\end{tabular}

Sumber: Statistik Kesejahteraan Rakyat Kabupaten Bojonegoro, 2018

Jika dibandingkan dengan APS, besaran APM lebih rendah untuk setiap kelompok usia. Selisih antara nilai
APS dengan APM merupakan persentase mereka yang duduk di bangku sekolah tetapi tidak sesuai antara usia dan tingkatan sekolahnya. Tabel 5 memperlihatkan APM jenjang pendidikan SD sampai dengan SMA. Dari tabel tersebut terlihat bahwa APM pada setiap jenjang pendidikan masih belum mencapai angka 100 persen. Hal ini menunjukkan bahwa belum seluruh penduduk yang bersekolah menduduki jenjang pendidikan yang sesuai dengan usianya. Namun, jika disandingkan dengan target capaian APM SD/MI nasional yang disebutkan dalam RPJMN tahun 2015-2019, nilai capaian APM SD/sederajat pada tahun 2018 telah melampaui target RPJMN tahun 2019 yaitu sebesar 98,58 persen. Target APM SD/sederajat pada tahun berakhirnya RPJMN 2015-2019 adalah 91,3 persen. Dari semua tingkat pendidikan, APM SD/sederajat memiliki nilai paling tinggi, kemudian semakin menurun seiring meningkatnya jenjang pendidikan. Berdasarkan jenis kelamin, tidak terlihat perbedaan yang berarti antara APM laki-laki dan perempuan pada setiap jenjang pendidikan.

Banyaknya jumlah anak putus sekolah pada jenjang Sekolah Menengah Atas (SMA), yaitu sebanyak 2.221 orang, seperti yang telah disebutkan di atas mendapatkan perhatian dari Pemerintah Kabupaten Bojonegoro. Hal ini sejalan dengan Peraturan Pemerintah (PP) Nomor 47 Tahun 2008 tentang Wajib Belajar yang mengharuskan setiap daerah meningkatkan program wajib belajar 9 tahun menjadi 12 tahun, yaitu sampai ke jenjang pendidikan menengah atas. Pemerintah Kabupaten Bojonegoro mencanangkan GAS untuk menggugah semangat pelajar dalam menempuh pendidikan dengan diimbangi pemberian dana pendidikan bagi siswa-siswi SMA/sederajat yang didapat dari pengelolaan DAK Bidang Pendidikan.

Pemerintah Kabupaten Bojonegoro berharap adanya pengelolaan DAK Bidang Pendidikan yang diwujudkan dalam pemberian bantuan dana pendidikan. Program yang sudah berjalan sejak tahun 2015 itu dapat membantu orang tua untuk membiayai pendidikan anaknya, sehingga tidak ada lagi keluhan masyarakat mengenai persoalan biaya pendidikan anak. Bantuan dana Pendidikan diharapkan dapat mengurangi jumlah anak putus sekolah pada jenjang SMA/sederajat.

\section{IMPLEMENTASI GERAKAN AYO SEKOLAH (GAS)}

Pada masa sekarang, pendidikan merupakan suatu kebutuhan primer. oleh karenanya, masyarakat mulai berlomba untuk mencapai pendidikan setinggi mungkin. Pemerintah pusat maupun daerah pun banyak yang menggulirkan program agar masyarakat semakin 
mudah mengakses dan memperoleh layanan pendidikan, sehingga tidak ada anak putus sekolah karena orang tua yang tidak bisa menyekolahkan anaknya.

Dalam menyukseskan program wajib belajar 9 tahun, Pemerintah Pusat mengeluarkan Inpres No. 5 Tahun 2006 tentang Gerakan Percepatan Penuntasan Wajib Belajar 9 tahun. Kebijakan tersebut menuntut agar wajib belajar 9 tahun dapat tuntas pada akhir tahun 2008. Dalam Inpres tersebut dijelaskan peningkatan persentase peserta didik sekolah usia 7-15 tahun sekurang-kurangnya sebesar 95 persen di akhir 2008. Dalam hal ini Provinsi Jawa Timur telah mencapai APK 99,74 persen. Pada tahun 2008 Jawa Timur telah merintis wajib belajar pendidikan dasar 12 tahun. Untuk melaksanakan program ini di tingkat propinsi dianggarkan dana APBN sebesar Rp. 100 miliar, sedangkan kabupaten/kota menyiapkan dana sebesar Rp. 80 miliar. Jumlah anggaran sebesar itu membuktikan bahwa pemerintah memandang program ini penting dan perlu dilaksanakan.

Setelah program wajib belajar 9 tahun tuntas, Kabupaten Bojonegoro selanjutnya memulai penyelenggaraan program wajib belajar 12 tahun. Kebijakan tersebut dituangkan dalam Peraturan Daerah (Perda) Kabupaten Bojonegoro Nomor 4 Tahun 2014 tentang APBD Tahun 2015. Pada Rekening Belanja Bantuan Keuangan Pemerintahan Desa tertera dana sebesar Rp. 20.105.500.000,- untuk DAK Pendidikan bagi siswa SMA/SMK/MA negeri/swasta sekabupaten Bojonegoro.

Pemerintah Kabupaten Bojonegoro melalui Dinas Pendidikan mencanangkan GAS bagi anak-anak Bojonegoro pada hari Senin tanggal 15 Juni 2015, pukul 09.00 WIB di pendopo Kecamatan Dander. Meskipun pemerintah pusat sudah memberikan bantuan pendidikan melalui Bantuan Operasional Sekolah (BOS), Program Indonesia Pintar (PIP), Program Keluarga Harapan (PKH), dan jenis-jenis bantuan lainnya, semua program masih belum mampu sepenuhnya menyentuh program wajib belajar 12 tahun.

GAS merupakan kebijakan lokal Pemerintah Kabupaten Bojonegoro untuk memperkuat Program Wajib Belajar Sembilan Tahun dengan memberikan bantuan berupa dana kepada anak-anak usia sekolah, khususnya di tingkat SMA/sederajat. DAK Pendidikan dari pemerintah kabupaten dapat membantu sebagian anak yang putus sekolah untuk kembali ke bangku sekolah. Jumlah dana bantuan yang diberikan adalah Rp 500.000,- per siswa per tahun pada tahun 2015 dan meningkat menjadi Rp 2.000.000,- di tahun 2016. Bantuan DAK Pendidikan ini diperuntukkan bagi warga Bojonegoro dan tidak diberikan pada warga selain Bojonegoro, walaupun siswa tersebut menempuh pendidikan di Kabupaten Bojonegoro. Persyaratan yang dibutuhkan untuk pencairan bantuan DAK Pendidikan adalah foto kopi Kartu Keluarga (KK) sebagai bukti bahwa siswa yang dapat bantuan adalah warga Kabupaten Bojonegoro. Selain itu, siswa juga harus menyerahkan surat keterangan aktif sekolah disertai kelas yang diduduki dari lembaga/sekolah asal. Ini diperlukan untuk menunjukkan bahwa siswa tersebut benar-benar masih aktif sekolah dan kelas yang didudukinya. Mereka juga menandatangani kwitansi keuangan bermatrai 3.000 rupiah.

“...Bantuan ini diberikan kepada pelajar tingkat SMA asli Bojonegoro. Artinya, meskipun pelajar tersebut belajar di luar Bojonegoro tetap memperoleh bantuan ini. Baik itu siswa dari keluarga miskin maupun kaya..." (Puji Widodo, Kabid Sekolah SMP/SMA/SMK Dinas Pendidikan Bojonegoro).

Penggunaan DAK di Kabupaten Bojonegoro diatur oleh Peraturan Bupati Bojonegoro (Perbup) No. 20 Tahun 2017 yang mengatur bahwa pengadaan DAK ditujukan pada sektor pendidikan dengan harapan agar program wajib belajar di Bojonegoro dapat berjalan lebih optimal. Seluruh warga Bojonegoro yang menduduki pendidikan tingkat SMA/sederajat memperoleh dana yang disediakan pemerintah kabupaten tanpa terkecuali. Pemerintah Bojonegoro sangat berharap dengan pemberian DAK yang dikhususkan pada pendidikan SMA/sederajat ini dapat mengurangi angka putus sekolah, sehingga putra/putri Bojonegoro tetap dapat bersekolah dan berkontribusi dalam pembangunan daerah.

Pemberian DAK Bidang Pendidikan dilaksanakan setiap tahun. Kegunaan DAK Pendidikan ini sematamata untuk memenuhi kebutuhan sekolah, misalnya membayar SPP serta membeli buku dan seragam sekolah. Adapun besaran dana yang diperuntukkan bagi siswa-siswi tingkat SMA/SMK/MA sederajat pada tahun 2015 sebagai berikut.

"Pemberian Dana Alokasi Khusus (DAK)
Pendidikan tahun 2015, yang baru saja
diberikan bagi anak sekolah di tingkat
SMA/SMK/MA sederajat sebesar Rp 500.000,--
bagi anak kelas X dan XI serta Rp 250.000,-
bagi anak kelas XII di seluruh Kabupaten
Bojonegoro tanpa melihat status orang tua,
telah meyakinkan masyarakat bahwa
pemerintah tidak main-main tentang 
Jurnal Kependudukan Indonesia | Vol. 14, No. 1, Juni 2019|77-92

keberlanjutan generasi penerus bangsa ini." (Kang Yoto, Mantan Bupati Bojonegoro)

Pemerintah Kabupaten Bojonegoro pada tahun 2016 mengalokasikan DAK Pendidikan dalam APBD sebesar Rp 98,6 miliar yang diperuntukkan bagi 49.445 siswa. Jumlah ini meningkat dibanding tahun 2015, yakni Rp. 7,216 miliar. Pada tahun 2016 besaran dana DAK Bidang Pendidikan yang diberikan kepada siswasiswi SMA/SMK/MA sederajat tersebut berubah sebagaimana Peraturan Bupati Bojonegoro Nomor 8 Tahun 2016 tentang Pedoman Pengelolaan DAK Bidang Pendidikan di Kabupaten Bojonegoro yaitu Rp 2.000.000,- bagi setiap siswa/siswi kelas X dan XI serta Rp 1.000.000,- bagi kelas XII. Siswa kelas XII memperoleh dana lebih sedikit karena mereka akan segera lulus sekolah. Namun untuk kelas X dan XI, uang tidak diterimakan semuanya. Jumlah yang diberikan kepada siswa sebesar Rp 1.000.000,-, sedangkan $\mathrm{Rp} 1.000 .000$,- ditabung atas nama siswa untuk kebutuhan sekolah.

Meskipun pada tahun 2017 pengelolaan pendidikan tingkat SMA telah diambilalih oleh Provinsi Jawa Timur, Pemerintah Kabupaten Bojonegoro tetap mengucurkan bantuan tersebut. Besaran bantuan DAK Pendidikan dievaluasi menyusul adanya efisiensi anggaran 40 persen akibat penurunan dana bagi hasil minyak dan gas bumi (DBH Migas) dan hasil pemeriksaan Badan Pemeriksa Keuangan (BPK) tentang pembeda antara siswa miskin dan kaya.

"Tahun ini ada klasifikasi anak dari keluarga mampu dan tidak mampu. Sebelumnya kami memberikan beasiswa kepada semua siswa baik miskin maupun kaya." (Puji Widodo, Kepala Bidang SMP Dinas Pendidikan Bojonegoro)

Alokasi DAK Pendidikan pada tahun 2017 adalah sebesar Rp 48 miliar. Pada tahun 2017 besaran dana tersebut telah mengalami peningkatan sebagaimana Peraturan Bupati Bojonegoro Nomor 20 Tahun 2017 tentang Perubahan Atas Peraturan Bupati Nomor 8 Tahun 2016 tentang Pedoman Pengelolaan DAK Bidang Pendidikan di Kabupaten Bojonegoro dan dibedakan berdasarkan kondisi ekonomi orang tua atau golongan profesi dan jenjang kelas anak. Peningkatan besaran ini terlihat pada setiap siswa/siswi kelas X dan XI dari orang tua yang tergolong miskin yang mendapatkan dana sebesar Rp 2.100.000,-.

Sesuai dengan Peraturan Bupati Bojonegoro Nomor 20 Tahun 2017 tentang Perubahan Atas Peraturan Bupati Bojonegoro Nomor 8 Tahun 2016 tentang Pedoman
Pengelolaan DAK Bidang Pendidikan Kabupaten Bojonegoro (Pasal 6) besaran DAK Bidang Pendidikan adalah sebesar Rp 2.100.000,- untuk setiap siswa kelas $\mathrm{X}$ dan kelas XI yang orang tuanya termasuk dalam kategori miskin/penerima Program Keluarga Harapan (PKH). Sedangkan siswa kelas XII yang orang tuanya termasuk dalam kategori yang sama menerima sejumlah Rp 1.050.000,- setiap siswa. Selanjutnya, dana bantuan berjumlah Rp 2.000.000,- untuk setiap siswa kelas $\mathrm{X}$ dan kelas XI yang orang tuanya termasuk kategori non miskin/mampu. Dana sebesar Rp 1.000.000,- diberikan untuk setiap siswa kelas $\mathrm{X}$ dan kelas XII yang orang tuanya adalah Pegawai Negeri Sipil (PNS) golongan I dan II. Jumlah dana sebesar Rp 500.000,- diberikan untuk siswa kelas XII yang orang tuanya adalah Pegawai Negeri Sipil (PNS) Golongan I dan II. Selanjutnya, sebanyak Rp 500.000,- diberikan kepada setiap siswa kelas X dan kelas XI yang orang tuanya adalah PNS Golongan III serta IV dan Rp 250.000,- bagi setiap siswa kelas XII dengan orang tua dalam kategori yang sama.

Pengelolaan DAK Bidang Pendidikan ini juga melibatkan pemerintah desa dan LKM di kelurahan masing-masing. Di Desa Banjarsari, Kecamatan Trucuk, Kabupaten Bojonegoro yang merupakan lokasi penelitian pengelolaan DAK Bidang Pendidikan dilakukan pemerintah desa mulai dari tahap pengajuan usulan penerima bantuan, pengajuan pencairan dana setelah ditetapkannya pagu anggaran oleh Bupati, penyaluran dana kepada penerima bantuan, serta pertanggungjawaban yang harus dilakukan pemerintah desa terhadap penggunaan anggaran DAK Bidang Pendidikan yang diperoleh melalui transfer dana dari Rekening Kas Umum Daerah (RKUD) ke Rekening Kas Desa. Mekanisme pengelolaan DAK Bidang Pendidikan di Desa Banjarsari sesuai dengan Peraturan Bupati Bojonegoro Nomor 20 Tahun 2017 tentang Perubahan Atas Peraturan Bupati Nomor 8 Tahun 2016 Tentang Pedoman Pengelolaan DAK Bidang Pendidikan di Kabupaten Bojonegoro. Namun dalam pelaksanaannya masih ditemui permasalahan, dimulai dari adanya kekeliruan saat pendataan penerima DAK Bidang Pendidikan.

GAS yang diresmikan Pemerintah Kabupaten Bojonegoro pada tahun 2015 tersebut memberikan dampak yang positif bagi dunia pendidikan di Kabupaten Bojonegoro. Dengan adanya dana bantuan pelajar dapat mewujudkan mimpinya untuk menggapai cita-cita. Menurut Puji Widodo, Kabid Sekolah SMP/SMA/SMK Dinas Pendidikan Bojonegoro, gerakan ini terbukti telah merubah pemikiran masyarakat tentang pentingnya pendidikan untuk masa depan. 
"Selain itu, jumlah siswa-siswi yang sekolah formal juga terus menunjukkan kenaikan. Dari data dinas pendidikan jumlah siswa kelas $X$ SMA/SMK/MA tahun 2014/2015 sekitar 16.923 naik menjadi 17.462 siswa pada tahun 2015/2016. Kenaikan jumlah siswa yang melanjutkan ke tingkat SMA sederajat tersebut juga merupakan wujud dari keberhasilan Pemkab Bojonegoro dalam melaksanakan Gerakan Ayo Sekolah. Dengan adanya bantuan DAK juga merupakan salah satu upaya Pemkab untuk menyukseskan Gerakan Ayo Sekolah. Sehingga diharapkan ke depannya tidak ada lagi siswa/siswi yang putus sekolah atau tidak melanjutkan." (Kabid Sekolah SMP/SMA/SMK Dinas Pendidikan Bojonegoro).

“...Dengan adanya beasiswa ini, tidak ada lagi siswa di Bojonegoro yang putus sekolah alias drop out. Sebab selama ini masih ada siswa SMA sederajat yang drop out dari sekolah. Sehingga membuat angka partisipasi kasar atau APK pendidikan masih membutuhkan perhatian khusus..." (Kabid Sekolah SMP/SMA/SMK Dinas Pendidikan Bojonegoro).

Laurencia Estela R, Siswi SMA Katolik IGN Slamet Riyadi Kabupaten Bojonegoro memperoleh bantuan langsung DAK Pendidikan sebesar Rp 2.000.000,- pada tahun 2016. Bantuan yang diterima sangat bermanfaat bagi siswa/siswi Bojonegoro maupun orang tua karena dapat meringankan beban biaya sekolah. Bantuan tersebut benar-benar dimanfaatkan untuk keperluan pendidikan, baik untuk membeli buku, sepatu, tas maupun keperluan lainnya. Bantuan tidak digunakan untuk bersenang-senang seperti membeli telepon genggam ataupun kebutuhan konsumtif lainnya.

“...Hidup di Bojonegoro itu enak. Pendidikannya terjamin," (Laurencia Estela R, Siswi SMA Katolik IGN SlametRiyadi, Bojonegoro).

“...Mimpi-mimpi saya yang dulunya seperti tidak tercapai sekarang bisa tercapai dengan bantuan ini,"(Laurencia Estela R, Siswi SMA Katolik IGN SlametRiyadi, Bojonegoro).

Hal senada juga disampaikan Azhari Anhar, siswa MA Islahiyah Kalitidu yang mengaku bantuan DAK pendidikan dapat mencukupi kebutuhan sekolahnya. Bantuan DAK tersebut digunakan untuk membeli buku, sepatu, tas maupun keperluan lainnya.
“..Bantuan ini sangat membantu meraih citacita saya melanjutkan kuliah di jurusan bisnis," (AzhariAnhar, Siswa MA Islahiyah Kalitidu, Bojonegoro).

Tujuan pengelolaan DAK Bidang Pendidikan adalah meminimalisir jumlah anak putus sekolah, meningkatkan Angka Partisipasi Kasar (APK), dan membiayai kebutuhan sekolah. Ketiga tujuan tersebut belum tercapai secara maksimal karena masih terdapat berbagai permasalahan yang menghambat. Tujuan mengurangi jumlah anak putus sekolah belum berjalan maksimal karena kebanyakan dari mereka masih lebih memilih untuk bekerja dan tergiur dengan gaji/penghasilan yang mereka dapatkan bila dibandingkan dengan jumlah dana DAK Bidang Pendidikan. Oleh karena itu, perlu adanya rangkaian kegiatan seperti sosialisasi atau penyuluhan kepada masyarakat mengenai pentingnya pendidikan, terutama wajib belajar 12 tahun. Kegiatan tersebut dilaksanakan oleh pemerintah desa bersama dengan Karang Taruna, Lembaga Kemasyarakatan, PKK, dan kelompok lainnya.

Tabel 6 menunjukkan bahwa persentase APK pada jenjang SMA/sederajat di Kabupaten Bojonegoro tahun 2018 adalah sebesar 79,64 persen. Keadaan ini sama dengan satu tahun sebelumnya (2017), yaitu APK pada jenjang SMA/SMK/MA sederajat terbilang masih rendah $(23,94 \%)$. Oleh karenanya, pemerintah desa perlu bekerja sama dengan Dinas Pendidikan maupun instansi terkait lainnya untuk memecahkan permasalahan ini.

Tabel 6. Angka Partisipasi Kasar (APK) Formal dan Nonformal Penduduk Menurut Jenis Kelamin dan Jenjang Pendidikan, 2018

\begin{tabular}{lccc}
\hline Jenis Kelamin & SD & SMP & SMA \\
\hline Laki-laki & 105,59 & 96,52 & 72,97 \\
Perempuan & 101,50 & 97,14 & 89,24 \\
\hline Bojonegoro & 103,53 & 96,82 & 79,64
\end{tabular}

Sumber: $\quad$ Statistik Kesejahteraan Rakyat Kabupaten Bojonegoro, 2018

Efektivitas pelaksanaan GAS di Kabupaten Bojonegoro dapat dilihat dari data persentase angka putus sekolah SMA/SMK/MA yang dikeluarkan oleh Dinas Pendidikan Kabupaten Bojonegoro Tahun 2013-2017. Data tersebut menunjukkan penurunan angka putus sekolah di Kabupaten Bojonegoro pada jenjang pendidikan SMA/SMK/MA setelah adanya Program GAS (gambar 3). Pada tahun 2013 sebelum adanya Program GAS persentase angka putus sekolah pada 
jenjang pendidikan SMA/SMK/MA adalah 0,70 persen dan mengalami penurunan menjadi 0,64 persen pada tahun 2014. Selanjutnya persentase angka putus sekolah terus mengalami penurunan, yaitu menjadi 0,59 persen pada tahun 2016 dan pada tahun 2017 kembali menurun menjadi 0,50 persen.

\section{Gambar 3. Persentase Putus Sekolah SD/MI, SMP/MTs dan SMA/SMK/MA Kabupaten Bojonegoro, Tahun 2013- 2017}

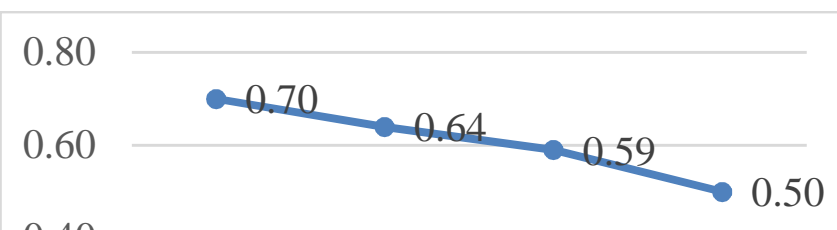

\subsection{0}

\subsection{0}

\subsection{0}

\section{$\begin{array}{llll}2013 & 2014 \quad 2015 \quad 2017\end{array}$}

Sumber: Dinas Pendidikan Kabupaten Bojonegoro, 2013, 2014, 2015, 2016 dan 2017

Seperti telah dikemukakan sebelumnya, kegunaan DAK pendidikan adalah untuk pembiayaan sekolah seperti membayar SPP dan membeli buku sekolah. Namun demikian, beberapa penerima dana DAK telah menyalahgunakan dana tersebut untuk membeli telepon genggam dan kebutuhan lainnya. Penyebab adanya penyalahgunaan ini karena mereka baru mendapatkan dana secara langsung setelah lulus sekolah.

Permasalahan lain yang dihadapi terkait ketepatan sasaran penerima dana. Penetapan sasaran penerima DAK Bidang Pendidikan di Desa Banjarsari dilakukan melalui pendataan dari tingkat RT di setiap dusun. Dari pendataan tersebut ditemui permasalahan kekeliruan data yang di antaranya adalah salah kelas yang diduduki, belum terdata dan ada anak yang putus sekolah tetapi masih terdata sebagai penerima DAK Bidang Pendidikan. Permasalahan ini dapat diatasi melalui pengajuan revisi nama-nama siswa yang belum terdata serta kelas yang diduduki siswa dengan mencantumkannya dalam laporan pertanggungjawaban (LPJ) penggunaan dana atas pencairan tahap pertama. Dengan demikian, program ini tepat sasaran sesuai dengan persyaratan dalam pedoman pengelolaan DAK Bidang Pendidikan. Selanjutnya, ada ketidaksesuaian besaran dana yang disalurkan oleh Pemerintah Desa Banjarsari kepada penerima DAK Bidang Pendidikan dengan aturan karena adanya penurunan DBH Migas di pertengahan tahun 2017 serta pemotongan atas lebih bayar DBH berdasarkan Peraturan Direktur Jenderal
Perimbangan Keuangan Nomor PER-1/PK/2017 tentang Tata Cara Pemotongan Atas Lebih Bayar Dana Bagi Hasil Triwulan Satu pada tahun anggaran 2017. Ini berdampak pada pemotongan setiap anggaran dalam APBD, termasuk juga pagu anggaran DAK Bidang Pendidikan yang diperoleh Pemerintah Desa Banjarsari dan pengurangan dana yang disalurkan kepada penerima DAK Bidang Pendidikan.

Terkait pengajuan usulan penerima DAK Bidang Pendidikan, masih terdapat beberapa desa di Kabupaten Bojonegoro yang terlambat dalam mengajukan proposal pencairan dana. Keterlambatan pengajuan pencairan dana yang dilakukan oleh beberapa desa tersebut berimbas pada terhambatnya pencairan dana dari Badan Pengelolaan Keuangan dan Aset Daerah (BPKAD) Kabupaten Bojonegoro. Akibatnya, penyaluran dana kepada penerima DAK Bidang Pendidikan juga ikut mengalami keterlambatan.

Untuk menyukseskan GAS Bupati Bojonegoro membuka lomba dengan cara pertama, peserta harus mendapatkan 5 kawan berusia 13-18 tahun yang belum/putus sekolah, memfoto dan men-tag ke akun Instagram:_*@ _kangyotobgoro*_. Kedua adalah meyakinkan mereka agar mau sekolah. Peserta harus berhasil membuat minimal tiga orang dari mereka menyatakan siap dan mau sekolah. Peserta membuat video berdurasi kurang dari satu menit dan mengupload di instagramanda, tentang usaha yang dilakukan untuk meyakinkan teman agar mau sekolah dan pernyataan kesediaan teman itu untuk sekolah lagi. Pesrta kemudian mengirimkan/tag ke akun Instagram Kang Yoto. Ketiga, peserta menuliskan nama, alamat dan nomor telepon genggam, beserta rencana pilihan sekolah (paket B, C atau sekolah formal) yang akan diambil teman yang diajak. Keempat, peserta menjadi perantara teman yang diajak dengan pihak Pemerintah Desa untuk dimasukkan dalam daftar calon penerima DAK Bidang Pendidikan dari pemerintah kabupaten. Bagi 25 orang pertama yang memenuhi point 1,2 dan 3 diberikan pulsa senilai Rp 100.000,-. Ada juga hadiah tambahan berupa tiket gratis masuk GoFun bagi 500 orang pengirim pertama.

"DAK Pendidikan ini adalah bentuk apresiasi kepada anak-anak di Bojonegoro yang masih ingin melanjutkan ke jenjang sekolah tapi terbentur ekonomi. Ayo semangat bersekolah Tidak ada alasan lagi untuk tidak melanjutkan pendidikan. Mari kita jadikan Bojonegoro menjadi daerah yang kaya dengan sumber daya manusia berkualitas. Mari wujudkan Wong Jonegoro lebih sehat, lebih cerdas, lebih 
produktif dan lebih bahagia," (Kang Yoto, Mantan Bupati Bojonegoro)

\section{KESIMPULAN}

Pendidikan adalah investasi SDM di masa depan. Menghadapi berbagai perubahan yang terjadi di era globalisasi dengan persaingan yang semakin tinggi dibutuhkan SDM yang handal dengan bekal pendidikan yang semakin tinggi. Pembangunan SDM melalui pendidikan diharapkan dapat mewujudkan sumber daya yang lebih berkualitas dengan pendidikan yang semakin tinggi. Untuk itu diperlukan kerjasama dengan berbagai sektor terkait.

Program wajib belajar 9-12 tahun yang bertujuan agar penduduk dapat mengenyam pendidikan setara Sekolah Menengah Pertama (SMP) hingga sekolah tingkat lanjutan atas mampu mendorong peningkatan APS kelompok usia ini, dan dapat mengurangi jumlah penduduk kelompok usia ini yang belum/tidak berada di bangku pendidikan (baik formal maupun nonformal) meskipun belum optimal. Artinya akses dan kesadaran penduduk Kabupaten Bojonegoro pada kelompok usia ini untuk bersekolah terus meningkat.

Bantuan langsung DAK Bidang Pendidikan yang diberikan Pemerintah Kabupaten Bojonegoro sejak tahun 2015 telah mengurangi angka putus sekolah atau siswa SMA/sederajat. Persentase angka putus sekolah SMA/SMK/MA Kabupaten Bojonegoro Tahun 20132017 mengalami penurunan meskipun belum signifikan $(0,20$ persen $)$. Program belum sepenuhnya efektif karena adanya permasalahan yang terjadi selama pelaksanaan pengelolaan DAK Bidang Pendidikan di beberapa desa di Kabupaten Bojonegoro. Pemerintah desa di Kabupaten Bojonegoro seharusnya melakukan pemantauan Bagi penerima DAK Bidang Pendidikan terhadap penggunaan dana agar terhindar dari pemanfaatan dana yang tidak sesuai dengan kegunaannya.

Kebijakan desentralisasi dan otonomi pendidikan berdasarkan legislasi nasional yang berlaku hingga sekarang belum mampu mengurangi, tetapi justru cenderung menambah, ketergantungan pemerintah provinsi dan kabupaten/kota terhadap pemerintah pusat. Ketergantungan itu bukan hanya dalam pendanaan, tetapi juga dalam perumusan kebijakan dan program (pembangunan) pendidikan bagi daerah masingmasing. Oleh karena kapasitasnya yang belum berkembang, sebagian besar kebijakan dan program pendidikan daerah "meniru" apa yang dilakukan oleh pusat sehingga tidak dapat dibedakan antara kebijakan dan program pemerintah pusat dan kebijakan serta program asli daerah otonom. Akibatnya, terjadilah tumpang tindih yang tak perlu antar program pembangunan pendidikan antar tingkat pemerintahan sebagai suatu bentuk pemborosan.

\section{DAFTAR PUSTAKA}

Ace, S. (1999). Pendidikan, Investasi SDM dan Pembangunan: Isu, Teori, dan Aplikasi. Jakarta: Pusat Informatika, Badan Penelitian Pendidikan dan Kebudayaan.

Adioetomo, S. M. (2005). "Bonus Demografi Menjelaskan Hubungan antara Pertumbuhan Penduduk dengan Pertumbuhan Ekonomi”. Disampaikan pada Upacara Pengukuhan Jabatan Guru Besar Tetap dalam Bidang Ekonomi Kependudukan pada Fakultas Ekonomi Universitas Indonesia, Jakarta 30 April 2005.

Badan Perencanaan Pembangunan Nasional [Bappenas]. (2018). Demografi Pembangunan. Jakarta: Badan Perencanaan Pembangunan Nasional.

Badan Pusat Statistik [BPS]. (2018). Indikator Kesejahteraan Rakyat Kabupaten Bojonegoro 2018. Bojonegoro: Badan Pusat Statistik Kabupaten Bojonegoro.

Badan Pusat Statistik [BPS]. (2018). Statistik Pendidikan Jawa Timur 2018. Surabaya: Badan Pusat Statistik Provinsi Jawa Timur.

Badan Pusat Statistik [BPS], \& United Nations Population Fund (UNFPA). (2015). Proyeksi Penduduk Kabupaten/Kota Provinsi Jawa Timur 2010-2020. Jakarta: Badan Pusat Statistik.

Creswell, J. W. (2010). Research Design: Pendekatan Kualitatif, Kuantitatif, dan Mixed. Yogyakarta: Pustaka Pelajar.

Miles, M. B., \& Huberman, A. M. (1992). Analisis Data Kualitatif. Terjemahan Tjetjep R.R. Jakarta: UI Press.

Neuman, W. L. (1997). Social Research Methods: Qualitative and Quantitative Approaches. London: Allyn and Bacon.

Ogawa, N., Jones, G. W., \& Williamson, J. G. (Ed.) (1993). Human Resources in Development Along the Asia-Pacific Rim. Singapore: Oxford University Press.

Okezone, "5.000 Anak di Bojonegoro Putus Sekolah", 17 Juni 2015, (online), http://news.okezone.com/read/2015/07/340/118 2901/5-000-anak-di-bojonegoro-putus-sekolah, diakses pada 30 Juli 2015. 
Jurnal Kependudukan Indonesia | Vol. 14, No. 1, Juni 2019|77-92

Pemerintah Kabupaten Bojonegoro. (2016). Peraturan Bupati Bojonegoro Nomor 8 Tahun 2016 tentang Pedoman Pengelolaan Dana Alokasi Khusus Bidang Pendidikan di Kabupaten Bojonegoro. Bojonegoro: Pemerintah Kabupaten Bojonegoro.

Pemerintah Kabupaten Bojonegoro. (2016). Peraturan Bupati Bojonegoro Nomor 20 Tahun 2017 tentang Perubahan Atas Peraturan Bupati Nomor 8 Tahun 2016 tentang Pedoman Pengelolaan Dana Alokasi Khusus Bidang Pendidikan di Kabupaten Bojonegoro. Bojonegoro: Pemerintah Kabupaten Bojonegoro.

Rosadi, F. (2017). Ketimpangan Dalam Kacamatan Demografi. Media Keuangan, 12(119), 15-17. Diakses

dari http://103.93.189.54/Home/Detail/62/ketimpang an-dalam-kacamata-demografi

Sen, A.(1999). Development as Freedom. New York: Oxford University Press.

Simanjuntak, P. J. (1985). Pengantar Ekonomi Sumber Daya Manusia. Jakarta: Lembaga Penerbit Fakultas Ekonomi Universitas Indonesia. 